What do his speeches in the Circe chapter mean?

Bloom is articulate of speech, inarticulate of mind; Stephen is inarticulate of speech, articulate of mind. For Molly mind and speech are the sameshe talks to herself to think, and thinks out loud to speak. Together they complement each other, and make a poem that speaks in three voices at once, as Hamlet when he speaks is a distraught prince of Denmark, a poet as enigmatic as Stephen Dedalus, and, ineluctably, the voice of Shakespeare.

Is not Joyce in many ways more like Bloom than Stephen? Professor Ellmann has found a real Martha Clifford; Nora Barnacle's letters are as much like Molly's monologue as Joyce's city-dwelling habits are like Bloom's.

Looked at this way, the novel becomes a solipsistic poem which accepts its inability to know another mind, and thus boldly stands forth not only as an epiphany of kinds of life in our time, uncompromisingly objective, but as an epiphany of art itself, the work of one mind and one sensibility, uncompromisingly subjective.

Opposites cooperate, said Heraclitus; opposites meet, said Blake; unity, says R. Buckminster Fuller, involves at least two things. I am suggesting, then, that the important voice in Ulysses is not the naturalistic one, which can stand beside that of Joyce's masters Jacobsen, Tolstoy, Ibsen, and Flaubert. It is rather the inner voice of the novel, the poetic voice of the symbols, that gives the work its coherence and its profoundest harmony. ${ }^{*}$

* Read at Princeton University as the Eberhardt Faber Lecture for 1973.

CRITICISM / MAR J ORIE G. PERLOFF

\title{
Pound and Rimbaud: The Retreat from Symbolism
}

When A Draft of XXX Cantos appeared in 1930, William Carlos Williams remarked with characteristic insight: "A criticism of Pound's Cantos could not be better concerned, I think, than in considering them in relation to the principal move in imaginative writing today-that away from the word as symbol toward the word as reality." 1

This was in 1931 but today, some forty years later, critics are still talking all too frequently of the "central symbolism," the "thematic design," or the "major form" of the Cantos, as if Pound's encyclopedic poem, written over a period of sixty years, could be deciphered by what the poet himself called disparagingly "an Aquinas-map." ${ }^{2}$ To understand Pound's gradual shift from what Williams called "the word as symbol toward the word as 
reality, we might profitably consider Pound's debt to the late nineteenthcentury French poet who, in the words of Delmore Schwartz, "tried out the whole century in advance" 3 -Rimbaud.

In 1957, a year after the publication of Rock-Drill (Cantos 85-95), Pound published, in a limited edition of 500 copies printed in Milan, a slender volume called Rimbaud, which contains five French poems with Pound's translations on the facing pages: Rimbaud's "Au Cabaret-Vert," "Comedie en trois baisers," "Venus Anadyomene," and "Les Chercheuses de poux," as well as Laurent Tailhade's "Rus."4 In his introductory note, Pound declares: "The Study [in] French Poets appeared in the Little Review nearly 40 years ago. The student hoped that the selection would stimulate thought and possibly one or two of the thousands of aspirants for literary glory would take up the matter. As no adequate translations have yet appeared, he now takes pity on those who haven't had time to learn French but might like to know what the French authors were writing about, and herewith starts to provide a guide to the meaning of the poems then given in the original only" (p. 5).

But having translated Rimbaud, Pound evidently lost interest in the project, and he never did provide his projected guide to the other fourteen poets included in his original Little Review anthology. This is a pity because Pound's Rimbaud translations, limited though they are to four early, relatively minor lyrics, are surely among the best we have. To give just one example, here is the first quatrain of "Au Cabaret-Vert":

Depuis huit jours, j’avais déchiré mes bottines

Aux cailloux des chemins. J'entrais à Charleroi.

-Au Cabaret-Vert: je demandai des tartines

De beurre et du jambon qui fût à moitié froid.

Pound's translation renders in precise, idiomatic English the anecdotal immediacy and concreteness of the original:

Wearing out my shoes, 8th day

On the bad roads, I got into Charleroi.

Bread, butter, at the Green Cabaret

And the ham half cold.

In referring us back to his A Study in French Poets of 1918,5 Pound reminds us that his initial interest in Rimbaud coincided with the first burst of activity on the Cantos, which got under way, after the abortive First Draft of Cantos 1-3 in 1917, with the publication of Canto 4 in 1919, and, more significantly, with the composition of the Malatesta sequence in $1923 .^{6}$ 
These dates are important: in study after study, we read that the nineteenthcentury French poet who influenced Pound was Gautier, but we look in vain in the Cantos for echoes of the Parnassian mode of Emaux et Camées -a mode that does stand squarely behind Hugh Selwyn Mauberley. ${ }^{7}$ It is my contention that after 1920, with Mauberley behind him, Pound turned more and more from Gautier and "the 'sculpture' of rhyme" 8 to Rimbaud's particular brand of Imagism as model. Rimbaud's influence on Pound has gone largely unnoticed, no doubt because Pound paid no attention to Rimbaud's major works: the Saison en Enfer, the Illuminations, or even such late great poems as "Mémoire" and "Larme." But one must remember that Pound's interest in a given poet was almost always stylistic rather than thematic. Rimbaud's feverish self-conflict, his search for identity, his ambivalence about the Church or about sexual experience-these were matters in which Pound had not the slightest interest. What he could learn from Rimbaud, however, was how an American poet of 1920, brought up on Browning and the nineties, and having worked in close conjunction first with Yeats and then with Eliot, could escape from the Symbolist impasse.

Pound's quarrel with Symbolism began, of course, much earlier, and has been the subject of extensive discussion. ${ }^{9}$ In his study of Pound's aesthetic, Herbert Schneidau argues convincingly that Pound's Imagism was never merely, as Frank Kermode and others have suggested, a latter-day or local version of Symbolism, that Pound was, in fact, much less influenced by T. E. Hulme than by Ford Madox Ford's insistence on direct presentation, Flaubert's concept of "le mot juste," and Fenollosa's argument that Chinese characters and sentence patterns give us "vivid shorthand pictures of actions and processes in nature."10 As early as 1913, Pound criticized Yeats for being "subjective" like the French Symbolists, whereas "Mr. Hueffer [Ford] believes in an exact rendering of things. He would strip words of all 'association' for the sake of getting a precise meaning."11 In the same year, Pound began to refer appreciatively to Rimbaud, both in his "Paris Letter" for The New Age and in his columns for Poetry magazine. Talking of Corbière, for example, he says: "he has left only one book and this alone would set him apart from 'the French poets' and place him in that very narrow category which contains Villon and Rimbaud."12

In the essay "Vorticism," first published in 1914 and reprinted in GaudierBrzeska (1916), Pound took great pains to distinguish his own theory of poetry from Symbolist doctrine as he understood-or misunderstood-it. "Imagisme," he declares, "is not symbolism. The symbolists dealt in 'association,' that is, in a sort of allusion, almost of allegory. They degraded the symbol to the status of a word. . . . One can be grossly 'symbolic,' for example, by using the term 'cross' to mean 'trial.'"13 What Pound objects to, in other words, is that Symbolism is still essentially a mimetic art, the 
image (a) standing for something else $(b)$ behind it, as in Baudelaire's famed "correspondances" between the natural and the spirit world. Such dualism, Pound insists, is detrimental to poetry: "to use a symbol with an ascribed or intended meaning is, usually, to produce very bad art" (p. 86).

One can object, of course, that in the poetry of the great Symbolists from Nerval to Eliot, there is never such obvious one-to-one correspondence between the image and its referents. But Pound is purposely overstating the case because he wants to replace the polysemous discourse of Symbolist poetry with the language of pure presentation. "If I had the energy," he says, "to get paints and brushes and keep at it, I might found a new school of painting, of 'non-representative' painting, a painting that would speak only by arrangements in colour" (p. 87). This statement recalls a very similar comment made by Rimbaud in 1872: "We must root out painting's old habit of copying, and we must make painting sovereign. Instead of reproducing objects, painting must compel agitation by means of lines, colors, and shapes that are drawn from the outer world but simplified and restrained: genuine magic."14

By 1916, then, Pound was actively campaigning for a new non-representational art. But theory is one thing and practice another, and I cannot quite accept Schneidau's assumption that the poetry of Cathay (1915) and Lustra (1916) is post-Symbolist. Take "The Jewel Stairs' Grievance," Pound's version of a Chinese lyric by "Rihaku" ( $\mathrm{Li} \mathrm{Po}$ ), which Schneidau cites as an example of "reticence and presentational condensation" (p. 32).

The jewelled steps are already quite white with dew,

It is so late that the dew soaks my gauze stockings,

And I let down the crystal curtain

And watch the moon through the clear autumn.

(Personae, p. 132)

Even without Pound's prose gloss, ${ }^{15}$ it is evident that this is a lament for lost love, spoken by a high-born lady. The "jewelled steps" symbolize aristocratic or courtly status; the dew-soaked white gauze stockings stand for the defeat of something precious and fragile, and the letting down of the crystal curtain suggests the coming on of night and despair. Surely in this poem, Pound's images function symbolically rather than presentationally; the principle of substitution ( $a$ stands for $b$ ) still operates. ${ }^{16}$

An even more striking instance of the disparity between theory and practice at this stage in Pound's career is found in the so-called Ur-Cantos, ${ }^{17}$ published in Poetry in 1917. A number of passages from Pound's original Canto 1 find their way into the final versions of 2, 3, and 4, but in terms of form, this Ur-Canto has almost nothing in common with Pound's later work. It is still essentially a Browningesque dramatic monologue, an un- 
easy mixture of expostulation and image, in which the speaker alternately praises Browning, quarrels with his ghost, and wonders, somewhat querulously, whether he himself should "give up th' intaglio method"-the technique of his short Imagist poems-and write a long poem that might rival Sordello. He has self-doubts because Browning has already "worked out new form, the meditative, / Semi-dramatic, semi-epic story, / And we will say: What's left for me to do?"18 Certainly nothing in the Canto itself is likely to convince us that Pound has found a new way to use the Sordello story or its Troubadour analogues. Even the poem's rather monotonous blank verse and archaic speech patterns echo Browning's, for example,

“Were’t nót our lífe, your lífe, my lífe, exténded?

The imagery of Pound's Sordello Canto is also fairly conventional. After referring to the form of Browning's poem as the "rag-bag" the modern world needs "to stuff all its thoughts in," the poet wonders:

Say that I dump my catch, shiny and silvery

As fresh sardines flapping and slipping on the marginal cobbles?

This comparison of poetic invention to a creative "spilling out"-the dumping of a huge sardine catch on the "marginal cobbles" of Sirmio (Sermione), his beloved village on Lake Garda ${ }^{19}$-is the sort of explicit analogy Pound takes pains to repudiate in Gaudier-Brzeska. The image of the lake, for that matter, which runs through the entire Canto, is nothing if not Symbolist. Consider the following passage:

And the clouds bow above the lake, and there are folk upon them

Going their windy ways, moving by Riva,

By the western shore, far as Lonato,

And the water is full of silvery almond-white swimmers,

The silvery water glazes the up-turned nipple. (p. 119)

These lines, which reappear in revised form in what is now Canto 3 (the "folk" explicitly become "gods" and the "swimmers," "Maelids"), are hardly examples of "presentational immediacy" or "direct treatment of the thing." Like many a latter-day Symbolist, Pound here takes from nature only what he can use to compose the "objective correlative" of a Neoplatonic earthly paradise, a pastoral world of gods and nymphs in which the sunlight rains down ("Lo soleils plovil") and "the place is full of spirits." Near the end of the Canto, the poet remarks: 
No, take it all for lies.

I have but smelt this life, a whiff of it-

The box of scented wood

Recalls cathedrals. And shall I claim;

Confuse my own phantastikon,

Or say the filmy shell that circumscribes me

Contains the actual sun;

confuse the thing I see
With actual gods behind me? (p. 120)

This revealing passage, in which Pound slyly alludes to Mallarmé, ${ }^{20}$ suggests that he understood only too well the essential conventionality of his descriptions. Intuitively, he must have sensed that he was missing the woods for the trees-the "cathedrals" for the "box of scented wood," the circumscribing "filmy shell" for the "actual sun." No wonder that when he revised these early Cantos in 1924, Pound made an entirely fresh start. ${ }^{21}$

In the meantime, the search for models continued. In 1918, the Little Review published Pound's Study in French Poets, a 60-page essay which provided the Anglo-American reader with an extensive, if rather biased, anthology of modern French poetry, interspersed with Pound's critical commentary. The Study contains a large selection from the poetry of Corbière, Laforgue, and Rimbaud, followed by shorter samples of twelve less wellknown later poets such as Francois Jammes and Jules Romains. In his brief introduction, Pound says: "I do not aim at 'completeness.' I believe that the American-English reader has heard in a general way of Baudelaire and Verlaine and Mallarmé; that Mallarmé, perhaps unread, is apt to be slightly overestimated."22

This remark provides us with an important clue to Pound's thinking. We must remember that for most Anglo-American poets from Arthur Symons to Wallace Stevens, Baudelaire, Verlaine, and Mallarmé constituted a kind of Holy Trinity, although individual predilections naturally varied: Eliot considered himself a citizen of Baudelaire's "fourmillante cité," and Yeats was especially drawn to Verlaine, whereas Stevens was strongly influenced by Mallarmé as well as by the last major French Symbolist, Valery. If Pound had no use for these poets, it is surely because he dismissed their work as "Symbolist" without distinguishing between such minor neo-Symbolists as Fargue and Larbaud on the one hand, and a great creator of "clear visual images" like Baudelaire on the other. But dispassionate, objective judgment was never characteristic of Pound; he dismissed the Symbolists outright simply because he was looking for models who could teach him the rudiments of a non-representational art. "After Gautier," he thus announces airily, "France produced, as nearly as I understand, three chief and admirable 
poets: Tristan Corbière, perhaps the most poignant writer since Villon; Rimbaud, a vivid and indisputable genius; and Laforgue-a slighter, but in some ways a finer 'artist' than either of the others. I do not mean that he 'writes better' than Rimbaud. . . . Laforgue always knows what he is at; Rimbaud, the 'genius' in the narrowest and deepest sense of the term, the 'most modern,' seems, almost without knowing it, to hit on the various ways in which the best writers were to follow him, slowly" (pp. 6-7).

This is a peculiarly prophetic statement, for Pound could not know, in 1918 , that some of the "best writers" of our century-Williams, Crane, Roethke, Plath, the Black Mountain poets, O'Hara-were indeed to turn more and more from Symbolism to the stark juxtapositions of concrete images and the landscapes without depth of Rimbaud. In discussing Rimbaud's poems, Pound notes: "The actual writing of poetry has advanced little or not at all since Rimbaud. Cezanne was the first to paint, as Rimbaud had written-in, for example, 'Les Assis':

Ils ont greffé dans des amours épileptiques

Leurs fantasque ossature aux grands squelettes noirs

De leurs chaises; leurs pieds aux barreaux rachitiques

S'entrelacent pour les matins et pour les soirs!

Ces vieillards ont toujours fait tresse avec leurs sièges. (p. 23 $)^{23}$

What Pound means here, I think, is that, like Cezanne, Rimbaud uses images not for their symbolic weight but to distort "normal" perspective, in this case, to present a vision of sheer, overwhelming ugliness. "Les Assis" is a poem about old men who haunt public libraries, but we never see the Sitters as human beings. Rather, the poem presents human frames grafted in epileptic passion onto chairs, feet intertwining with the rachitic bars of furniture, skin turning into calico, and coat buttons that have the eyes of beasts. Rimbaud thus deforms reality; he uses palpable visual images, but they are such as the human eye has never encountered. The poem is a surrealistic fantasy in which bundles of tonsils and other bits and pieces of human anatomy merge mysteriously with inanimate objects, creating new imaginary forms.

Later in the essay, Pound pays Rimbaud the supreme compliment: he calls line 6 of "Roman" ("L'air est parfois si doux, qu'on ferme la paupière") "worthy of To-em-Mei" (p. 25). This is a reference to the Chinese poet Tao Yuan-ming, whose series of short poems in the Fenollosa manuscript became the basis for Pound's original lyric synthesis, "To-em-Mei's 'The Unmoving Cloud," which is the final poem in the Cathay sequence. ${ }^{24}$ As for "Comedie en trois baisers," Pound exclaims: "The subject matter is older 
than Ovid, and how many poets has it led to every silliness, every vulgarity! One has no instant of doubt here, nor, I think, in any line of any poem of Rimbaud's. The thing that stuns me in preparing this section of my essay is HOW, HOW, HOW! so much could have escaped me when I read him five years ago" (p. 26). This final candid sentence was omitted when Pound reprinted A Study in French Poets in Instigations (1920). Upon reflection, he evidently hated to admit that even in 1913, he had overlooked something as important as Rimbaud's genius. He concludes: "I wonder in what other poet will we find such firmness of colouring and such certitude" ( $p$. 26).

In 1928, Pound published A Draft of the Cantos 17-27. In the same year, he wrote a long letter to René Taupin, in response to specific questions that Taupin (who was preparing his book, L'Influence du Symbolisme Français sur la Poésie Americaine) had posed. This letter contains Pound's strongest statement in praise of Rimbaud. Despite the slapdash French, cryptic shorthand references, and misspellings that characterize Pound's long, rambling letter, its central points are perfectly clear:

(1) Pound strenuously objects to Taupin's hypothesis that Imagism derived from French Symbolism. "Symbole??," he asks, "je n'ai jamais lu 'les idées des symbolistes' sur se sujet. . . . Mais 'voui': l'idée de l'image doit 'quelque chose' aux symbolistes français via T. E. Hulme, via Yeat $<$ Symons $<$ Mallarmé. Come le pain doit quelque chose au vanneur de blé, etc" (SL, p. 281). He concedes that Imagist concepts of condensation and concentration may owe something to Symbolism via the Hulme cénacle of 1908 but points out that his own version of Imagism was never quite that of Amy Lowell, F. S. Flint, etc. "Fort difference entre Flint: (tolerance pour tous les fautes et imbécillités des poètes Francais.) Moi-examen très sévère-et intolérance" (p. 216).

(2) Pound came to nineteenth-century French poetry, in his own words, "relativement tard" (p. 216). "Ma connaissance des poètes fr. mod. et ma propagande pour ces poètes en Amerique (1912-17-23) venait en sens genérale aprés l'inception de l'Imagisme à Londres (1908-13-14)" (p. 28). This explanation squares with Pound's admission in A Study in French Poets that much had escaped him when he first read Rimbaud in 1913.

(3) Despite the inherent disparity between the French and the American imagination, the technique of French poetry from the time of Gautier to 1912 could serve as an example to any American poet of Pound's generation. "Que les poétes essentials, a cette étude, se reduissent à Gautier, Corbière, Laforgue, Rimbaud. Que depuis Rimbaud, aucun poète en France n'a inventé rien de fondamentale" (p. 217). Note that this a stronger statement than any Pound made in the 1918 essay: the notion that since Rimbaud there has been no fundamental invention in French poetry is a new 
one. Laforgue and Corbière now begin to assume a more subordinate role.

(4) Pound cites as one of his central aims the attempt to forge a systematic aesthetic based on Rimbaud's intuitive stylistic habits: "Ce que Rimbaud atteint par intuition (génie) dans certaines poèmes, érigé en esthétique conscient (?? peut-être)-je ne veux pas prendre une gloire injuste -mais pour tant que je sais. J'en ai fais une esthétique plus ou moins systématique-et j'ai pu citer certaines poemes de R. comme example" (p. 217).

Pound thus acknowledges the profound influence of Rimbaud's revolutionary aesthetic on his own conception of what a poem should be. But he admits that it is difficult to emulate Rimbaud's verbal magic. "Est-ce que il existe une langue anglais pour exprimer les lignes de Rimbaud? Je ne dis pas un traducteur capable de le faire, mais est-ce-que cette langue existe? (comme moyen)-et depuis quand?" (p. 218). Rimbaud is, in other words, regarded as the inventor of a new poetic language, a language so unique that Pound wonders whether it will "translate" into English. The implication is that he himself will rise to the challenge.

(5) Pound's interest in Rimbaud is, as I suggested earlier, wholly stylistic: "c'est certain que apart certains procédés d'expression-R. et moi n'avons point de rassamblance" (p. 217). Taupin, an extremely literal, positivistic critic, concluded from this comment that Pound could not have learned much from Rimbaud. "Ces deux poètes," he says, paraphrasing Pound, "n'ont aucun trait de caractère en commun: Pound ne doit au poète français que des procédés d'expression." 25

What Taupin totally misses here is that for Pound "des procédés d'expression" are the very heart of poetry, that even if he doesn't borrow specific lines and phrases from Rimbaud, he may still be adapting a poetic style. Indeed, in "How to Read" (1929), the essay in which Pound makes his famed distinction between the "three kinds of poetry"-"MELOPOEIA, wherein the words are charged, over and above their plain meaning with some musical property," "PHANOPOEIA, which is a casting of images upon the visual imagination," and "LOGOPOEIA, the dance of the intellect among words," "-Rimbaud is hailed as an inventor of phanopoeic poetry, second only to the great Chinese poets: "Rimbaud brought back to phanopoeia its clarity and directness. . . . In Rimbaud the image stands clean, unencumbered by non-functioning words; to get anything like this directness of presentation one must go back to Catullus ..."26

Pound thus discovered in Rimbaud the qualities he most esteemed in poetry: directness of presentation, the image as the "poet's pigment," ideogrammic terseness, and the avoidance of adjectives and other "non-functioning words" in favor of straightforward subject-verb-object syntactic patterns. But it is hardly surprising that Taupin missed the connection between the two poets, for his study of Symbolist influence on American poetry only 
goes up to 1920, the year Mauberley, with its identifiable Gautier tags and Laforguian ironies, was published. If we now compare Mauberley and the Cantos of the Mauberley period to the Malatesta sequence of 1923 and its aftermath, the radical transformation of Pound's style-a transformation in which Rimbaud surely played a part-will become much clearer.

II

Mauberley has a problematic place in the Pound canon. Throughout the twenties and early thirties, it was hailed as Pound's one indisputable masterpiece; thus Eliot declared in 1928: "I am quite certain of Mauberley, whatever else I am certain of. . . . This seems to me a great poem . . . a document of an epoch; it is . . . in the best sense of Arnold's worn phrase, a 'criticism of life." "27 F. R. Leavis called Mauberley "a great poem, and a weightier achievement than any single thing . . . to be found in Yeats."28 The New Critics generally followed this lead, the assumption being that whereas the Cantos suffered from what Eliot called, rather wistfully and apologetically, "an increasing defect of communication." 29 Mauberley, at least, had what Ronald Bottrall defined as a "method based on a symbolism having various strata of interpretation."30

In recent years, as the greatness of the Cantos has come to be increasingly recognized, the pendulum has swung. It is now fashionable to argue that Mauberley, far from being unlike the Cantos, is to be seen as an early sketch for them, a slighter work containing in embryo many of Pound's later themes and techniques. Hugh Witemeyer, for example, writes: "To unify his sequence [Mauberley], Pound employed the same device that he was to use in The Cantos: the assimilation of a number of historical and pseudohistorical figures to the archetypal patterns of quest and heroic struggle found in Homer's Odyssey." 31

This is true enough with respect to what Mauberley says. But if we look at the way the poem works, a rather different picture emerges. Take, for example, III (Part I), which contains Pound's scathing attack on the bad taste of the modern age, whether in art, religion, or politics. It begins:

The tea-rose tea-gown, etc.

Supplants the mousseline of Cos,

The pianola "replaces"

Sappho's barbitos.

Christ follows Dionysus

Phallic and ambrosial

Made way for macerations;

Caliban casts out Ariel.

(Personae, p. 189) 
"To use a symbol with an ascribed or intended meaning," Pound had said in Gaudier-Brzeska, "is, usually, to produce very bad art" (p. 86). Yet I count eight such symbols in these eight lines. Briefly, the "tea-rose teagown" symbolizes the vulgarity of modern dress in contrast to the delicate and beautiful "mousseline of Cos"-the Propertian tunic of Coan silk. ${ }^{32}$ The pianola, which reduces music to a punched sheet of paper to be played mechanically, is contrasted to Sappho's barbitos, that is, to the original lyre of poetry, which symbolizes, as Witemeyer puts it, "the ideal relationship between the musician and his music" as well as "the ideal relationship between music and poetry" (p. 189). In the second stanza, Dionysus symbolizes the "Phallic and ambrosial" rites of pagan fertility, which have unfortunately been replaced by the "macerations" typical of Christianity. Ariel, the symbol of all that is delicate, airy, light, poetic, and spiritual, is cast out by Caliban, the symbol of earth, mindlessness, joylessness-the anti-poetic.

These rather facile contrasts between an idealized past and a vulgarized present continue throughout the poem as Pound produces symbol after symbol "with an ascribed or intended meaning." The "wafer," to give another example, symbolizes true communion; it is replaced by "the press," symbol of meaningless, vulgar communication-that is, of false communion. And so on. One feels that Pound begins with an idea, not with an image, and then sets about to find an objective correlative for that idea. Caliban vs. Ariel, pianola vs. Sappho's barbitos-all these items could be replaced by others without a real change in poetic effect. Moreover, despite is allusiveness and ellipses, the poem moves sequentially and logically from $a$ to $b$; it is not a collage of "super-pository" images or a "VORTEX, from which, and through which, and into which, ideas are constantly rushing." 33

We can find similar Symbolist dualism throughout Mauberley, and it would be tedious to go through this over-explicated poem step by step, pointing to all the examples. Let me note just a few of the more important. In the opening poem, "E. P. ODE POUR L'ELECTION DE SON SEPULCHRE," phrases like "wringing lilies from the acorn" (i.e., trying to make "pretty" poems from the roots of experience), "Obstinate isles" (dead conventions), and "Circe's hair" (dangerous beauty) function as symbols. In XII, a Laforguian parody-love poem, too heavily dependent on Eliot's "Prufrock" and "Portrait of a Lady," the symbolism is particularly one-dimensional. The "stuffed-satin drawing-room" of Lady Valentine all too obviously symbolizes an empty, loveless ambiance, while the final quatrain about Fleet Street has too much of the smart sarcasm that sometimes spoils Eliot's Sweeney poems:

Beside this thoroughfare

The sale of half-hose has 
Long since superseded the cultivation

Of Pierian roses. (Personae, p. 196)

Pieria was the place near Mount Olympus where the Muses were worshipped; the allusion is, once again, to a Sappho lyric. ${ }^{34}$ Pound's indignation that such cultivation (one wonders when Pierian roses were ever cultivated on Fleet Street) has been replaced by the "sale of half-hose" is reminiscent of Eliot's supercilious references to the typist laying out her food in tins while waiting for the "small house-agent's clerk, with one bold stare." The reference to "half-hose" is, in short, too pat a symbol for the vulgarity of the modern city.

"Medallion," the closing poem of Mauberley, presents an image of a debased "Anadyomene," rising from "the opening / Pages of Reinach" (an art history manual), which may well have been inspired by Rimbaud's frightful image of Venus Anadyomène in the poem by that title which Pound translated. But here again, images tend to have what Pound called disparagingly a "fixed value" (GB, 84). Thus the "half-watt rays" of the last stanza symbolize the twilight and feebleness of Mauberley's artistic inspiration, and the eyes that have turned "topaz" are eyes that have become lifeless-mere hard stones, jewels. ${ }^{35}$

The continuing controversy over the status of Mauberley (is he Pound? a persona who represents the failed aesthete? or sometimes Pound and sometimes this persona?) has obscured what seems to me much more important: that Pound was never quite at ease with the poetic materials of Mauberley, that he was trying too hard to write like Eliot. As he himself explained, twelve years later: "at a particular date in a particular room, two authors ... decided that the dilutation of vers libre, Amygism, Lee Masterism, general floppiness had gone too far and that some counter-current must be set going. . . . Remedy prescribed 'Emaux et Camèes' (or the Bay State Hymn Book). Rhyme and regular strophes. Results: Poems in Mr. Eliot's second volume . . . also 'H. S. Mauberley'. Divergence later." ${ }^{6}$ No wonder Eliot preferred Mauberley to all of Pound's other poems, for Mauberley is the one poem of Pound's that Eliot might have written himself. It represents the height of the Laforgue and Gautier influence, filtered down via Eliot's "Prufrock," "Portrait of a Lady," and the 1920 quatrain poems. But whereas Eliot's symbols have great richness, suggesting a broad range of meanings, Pound's symbolic mode tends toward one-to-one correspondence, annoying in its schematic neatness. "Half-hose" (modern vulgarity) versus "Pierian roses" (classical splendor)-it all seems too easy.

The lessons of Rimbaud-or, for that matter, those of Fenollosa, Ford, and Flaubert-had not, then, been mastered by 1920. Practice had not yet caught up with the theory that the "proper and perfect symbol is the natural 
object" (LE, p. 9). We can see Pound's dilemma in the early Cantos, which contrary to general opinion, do not yet use the presentational method. I have already spoken of the conventional symbolism of Ur-Canto 1, but Canto 4, first published in 1919 in what was substantially its final version, illustrates the same points. Here is the opening:

Palace in smoky light,

Troy but a heap of smouldering boundary stones,

ANAXIFORMINGES! Aurunculeia!

Hear me. Cadmus of Golden Prows! ${ }^{37}$

"ANAXIFORMINGES" is the Greek word for "Lords of the Lyre"; the reference is to Pindar's Second Olympian Ode, which begins with the lines: "Hymns that are lords of the lyre, what god, what hero, what man shall we sing of?" 38 Whether we take this reference as a straightforward allusion to the heroism of war or, conversely, as a bit of ironic debunking, since Pound frequently disparaged the pompous bombast of Pindar, ${ }^{39}$ clearly the four lines convey the tension between war and love, destruction and rebirth. The opening image of burning Troy, the archetypal destroyed city, will be juxtaposed, later in the Canto, to "Ecbatan of plotted streets," the ancient capital of Media Magna, a treasure house surrounded by seven walls of brilliant color-a recurrent image for Pound's Ideal City. "ANAXIFORMINGES" is juxtaposed to "Aurunculeia," the happy bride celebrated by Catullus in Carmen 61, and in the fourth line, Pound refers to Cadmus, the legendary hero who, with the guidance of Athena, sowed the dragon's teeth and founded the great city of Thebes. Pounds' implication thus seems to be that destructive violence gives way to marriage and the prospect of rebirth.

The opening of Canto 4 is often used as an example of Pound's superpository technique, his elliptical juxtapositions of words and phrases with no seeming logical connection or explanation, producing the effect of collage, of what Hugh Kenner has called "cultural overlayering." 40 But despite the concentration and condensation of Pound's lines, one should note that he is still organizing his images according to Symbolist principles: the fall of Troy and allusion to Pindar make up one symbolic cluster which is then juxtaposed to a second one: "Aurunculeia" and "Cadmus of Golden Prows." Destruction is countered by rebirth.

And so it goes throughout the Canto. In his line-by-line analysis, Walter Baumann possibly makes Canto 4 look more orderly, more structured than it really is ( $\mathrm{I}$ am not sure it is fair, for example, to refer to lines 5-12 as "The Dawn Lyric" or lines 69-81 as "The Noon Lyric"), ${ }^{41}$ but Baumann does manage to fit everything in the poem into his scheme, which he summarizes as follows: "Although there is no sequence of events in our Canto, we shall 
discover a progression of values, a moving away from baser passions towards the contemplation of spiritual beauty. ... Seen in this light, the theme can be restated as metamorphoses in different strata of love and civilization, as they affect a set of archetypal persons. . . . Pound reviews the march of civilization from the passion which destroys men and cities to the affection which is in harmony with the great mysteries of this world and leads men to the Ideal City. From the point of view of this dualism, metamorphosis is, to a certain extent, the intervention of divine justice." 42

Baumann may be overstressing the role of divine justice in Pound's value system, but otherwise his statement describes, quite accurately, the telescoping of Ovidian myths and Provençal romances that structures Canto $4-$ a telescoping that comes to a climax in lines 66-67 with the reference to the three pools-Pergusa, Gargaphia, and Salmacis-associated respectively with Pluto's rape of Persephone; Actaeon's spying upon Diana at the bath, which led to his tragic metamorphosis into a stag, hunted down by his own hounds; and the merging of the nymph Salmacis with Hermaphroditus so as to become a new bisexual creature. The remainder of the Canto contrasts these violent metamorphoses to a positive spiritual transformation, as symbolized by the pines at Takasago, the wedding of Aurunculeia, the Confucian tenet that "No wind is the king's wind," and finally the coming of Zeus to Danae in a shower of gold and the vision of Ecbatan. The Canto's coda, which begins in line 111 with the reference to a French Jesuit priest (Henry Jacques), addressing the "Sennin" (spirits of the air) on Mount Rokku, recapitulates the poem's earlier motifs (Cabestan, Tereus, Vidal) and culminates in the vision of Stefano da Verona's "Madonna in hortulo," a painting that recalls Cavalcanti's poetic description, some two hundred years earlier, of his Ideal Lady. In its 1919 version, the Canto ends with the line, "The Centaur's heel plants in the earth loam."43 Man's spiritual nature, in other words, is intimately connected with his physical being; when the two are in harmony, a new fertility is born. Canto 4 thus ends on a positive note: the "Madonna in hortulo" supplants the "heap of smouldering boundary stones" of Troy; love is born from the ashes of violence and decay.

Despite its complex network of materials and its radical disjunctions, then, Canto 4 does display a coherent thematic structure. From the opening motif of burning Troy to the dawn lyric about "choros nympharum," to the reference of light raining down "beneath the knees of the gods," the Canto's images function symbolically rather than presentationally. The description of the wedding torches as "blue agate casing the sky," for example, is hardly a case of what Pound called "constatation of fact"; in the context, the torches are clearly symbols of procreation just as the pines at Takasago traditionally connote long life and conjugal loyalty. ${ }^{44}$ 
In short, Pound had not yet hit upon the presentational method. In tracing the composition of the first sixteen Cantos, Myles Slatin makes clear that the first seven were completed by 1919, although 5-7 were much revised when they appeared as a group in Poems 1918-1921.45 Slatin further notes that Pound made no reference to the Cantos in his letters from 1919 to 1922 , some three years later. He seems to have come to some sort of impasse, not knowing what direction he wanted his epic poem to take. In May, 1922, Canto 8, not previously referred to, appeared in The Dial; it was to become, with some changes, the present Canto 2. "The appearance of this Canto," writes Slatin, "signalled the beginning of another period of intensive work on the long poem. This period, stretching from the spring of 1922 to the early part of 1925, was the climactic period of the poem's composition, for during it the poem-or at least the first part of it-took what is now its final shape" (p. 189).

Canto 9-the future Canto 8-was a Malatesta Canto. Pound refers to it in a letter to his mother on August 20,1922, and the four Malatesta Cantos were finished by the summer of 1923 and published in the July Criterion. Significantly, Pound's revisions of these Cantos for the 1925 book publication were minor, generally restricted to changes in lineation and occasional phrasing. "What is more important," says Slatin, "the design of the poem suddenly crystallized, perhaps partly as a result of the long and intensive labor which went into the Malatesta group. Within a month or perhaps two months of the publication of these Cantos, Pound had entirely revised the beginning of the poem and had come to the end of the composition of the first sixteen Cantos" (p. 191).

What caused this dramatic shift in Pound's style? We cannot attribute it wholly to the influence of Ford or Fenollosa, for Pound had been an ardent disciple of both for at least a decade, and yet, as we have seen, he continued to write, against his better judgment, a poetry of diluted Symbolism. The example of Ulysses is often cited, ${ }^{47}$ yet nothing could be less like Joyce's scholastically organized novel, that "Aquinas-map" in which each episode has its own Homeric analogue, symbol, technique, organ, color, and so on, than the Cantos, with their "constatation of fact," their cuts, their paratactic structure and autobiographical intrusions. The Waste Land, whose final form was, after all, largely determined by Pound's excisions and revisions, is a more plausible model, but Eliot's complex orchestration of water and fire symbols, of Hyacinth Garden and Unreal City, Game of Chess and empty Grail Chapel, is quite unlike the documentary, presentational mode of the Malatesta Cantos.

In 1923, just a few months before these Cantos appeared in the Criterion, Pound brought out, in the same journal, an article called "On Criticism in General."48 This was a rough sketch for the later essay "How to Read," in 
which Pound praised Rimbaud's "clean" images and phanopoeic "directness of presentation." Perhaps Rimbaud's example was one factor leading to the new mode of the Malatesta sequence. I am not arguing for a direct influence, but as Pound himself put it: "There are two ways of being influenced by a notable work of art: the work may be drawn into oneself, its mastery may beget a peculiar hunger for new sorts of mastery and perfection; or the sight of the work may beget simply a counterfeiting of its superficial qualities. This last influence is without value, a dodge ... of the mere searcher for novelty. The first influence means a new keenness of the ear, or a new flair for wording." 49 It is this "first influence," Pound's 1928 letter to Taupin suggests, that Rimbaud was to exert on the mature style of the Cantos.

wI

Much has been written on the background and themes of the Malatesta Cantos, and I don't wish here to go over familiar ground. Thomas Jackson has shown, quite conclusively, I think, that Malatesta is not just, as many commentators assume, ${ }^{50}$ Pound's hero-the Renaissance ruler as beneficent patron of art-but that the emphasis in these Cantos is on Sigismundo's very mixed motives and consequently dubious successes. ${ }^{51}$ From the beginning of Canto 8, Sigismundo is depicted as a man torn between his love for the arts and his concern for war-politics and "service money"; the public man, in Jackson's words, "is forever undoing the private man." If Sigismundo was responsible for the architectural splendors of the Tempio at Rimini, he was also the first man to use metal cannonballs. If he wrote beautiful love poems to Isotta degli Atti, he also engaged in the most petty materialistic power struggles with the Sforza and Medici dynasties.

The portrait of Malatesta that emerges from these Cantos is thus hardly novel: it takes us back to Burckhardt's understanding of the Italian Renaissance as a time of incredible tension between sexual brutality and courtly love, physical violence and artistic delicacy. To paraphrase Samuel Johnson, "if you were to read the Malatesta Cantos for their thematic interest, your patience would be so much fretted that you would hang yourself." And this is precisely how some readers have responded. "'Reading," says Donald Davie, "is an unsatisfactory word for what the eye does as it resentfully labors over and among these blocks of dusty historical debris." 52

Yet on closer inspection, Pound's manipulation of these "blocks of dusty historical debris" exerts a peculiar fascination. It is not just a matter of "cultural overlayering" or of juxtaposing love letters to battle scenes and to lists of building materials. I would posit that Pound's basic strategy herea strategy quite different from that of Canto 4 where thematically related myths are telescoped and aligned paratactically-is to create a flat surface, like that of a late Cezanne or Cubist painting, devoid of aerial perspective 
-a surface of linguistic distortions and contradictions that force the reader to participate in the poem's action. Just as Rimbaud invents cityscapes in which Swiss chalets on magic pulleys dissolve into Vesuvian craters and then into gorges spanned by little footbridges, so Pound dislocates language so as to create new landscapes.

The 1923 version of Canto 8 opens as follows:

Frater tamquam et compater carissime

(tergo

. . hanni de

.. dicis

.. entia

Equivalent to: Giohanni of the Medici, Florence)

Letter received, and in the matter of our Messire Gianozio

One from him also, sent on in form and with all due dispatch,

Having added your wishes and memoranda. ${ }^{53}$

Unlike the opening of Canto 4, with its juxtaposition of "ANAXIFORMINGES" and "Aurunculeia," this passage is not polysemous; as D. S. CarneRoss, in a general discussion of the Cantos, puts it, "the whole reverberating dimension of inwardness is missing. There is no murmuring echo chamber where deeps supposedly answer to deeps." ${ }^{4}$ But neither is the passage a rag-bag of dusty historical debris. Its strategy is best understood if we compare it to its source: a 1449 letter from Sigismundo to Giovanni di Medici. The original begins with the address:

Magnifice vir tamquam frater, et compater carissime. ${ }^{55}$

Pound lops off the standard form of address ("Magnifice vir") and reverses the next two words, emphasizing Sigismundo's rather oily appeal to his Medici patron as a true brother. Next, the sonorous formality of the address is undercut by a series of incomplete words, meant to reproduce what is on the back of the envelope ("tergo"). Here the reader has to fill in the first few letters of each word in order to make sense of the address: "Johanni de / Medicis / Florentia." The poet thus insists on our participation; it is up to us to fill in the blanks, to play the game. But just when we become accustomed to this strategy, Pound does a further turnabout and tells us matterof-factly: "Equivalent to: Giohanni of the Medici, Florence."

The lines, in short, do not convey information; rather, they take certain facts and present them from different linguistic perspectives (formal, florid Italian; broken Italian words; English translation) as if to undercut their historicity. Fact, in other words, is repeatedly transformed into fiction. Thus 
in the body of the letter, Pound takes Sigismundo's perfectly straightforward "Ho ricevuto vostra lettera" ("I have received your letter") and turns it into business English-"Letter received"-while the phrase "li preghi et recordi vestri" ("your best wishes and remembrances") becomes, by an absurd sleight-of-hand, "your wishes and memoranda," as if Rimini were dissolving into Wall Street.

Such linguistic indeterminacy is one of the central devices of these Cantos. Pound uses a variety of techniques to command our attention. Perhaps the simplest is condensation and modernization. In Canto 8, for example, Sigismundo's letter to Giovanni di Medici regarding his renewed alliance with Venice is a seven-line condensation of the original eighteen lines of prose, in which Sigismundo gives a formal explanation of the precise terms the Venetians have offered him, his military troubles caused by renewed flooding, and so on. Here is Pound's rendition:

\author{
Venice has taken me on again \\ At 7,000 a month, fiorini di Camera. \\ For 2,000 horse and four hundred footmen, \\ And it rains here by the gallon, \\ We have had to dig a new ditch. \\ In three or four days \\ I shall try to set up the bombards.

Such updating of history would not in itself make the Malatesta Cantos unique; it is a device many poets have used. But Pound's forte is to take a passage like the one just cited and then suddenly to switch back to the voice of the Renaissance chronicler, in this case describing the wedding of Bianca Visconti to Francesco Sforza:

Under the plumes, with the flakes and small wads of colour

Showering from the balconies ...

Arras hung from the railings; out of the dust,

With pheasant tails upright on their forelocks,

The small white horses, the

Twelve girls riding in order, green satin in pannier'd habits ...

Another common strategy is to set the original Italian side by side with a correct English translation so as to intensify and reinforce a central image; thus "non gli manchera la provixione mai" is followed by "never lacking provision," and the line "With his horsemen and his footmen" precedes "gente di cavallo e da pie." Or again, Pound may translate a given letter or document written in highly formal Italian so literally that it sounds like a parody 
in English. The best example of such satiric super-literalism is the letter of Sigismundo's five-year-old son, which Pound translates in Canto 9 with tongue-in-cheek pedantic fidelity: ${ }^{56}$

Magnificent and Exalted Lord and Father in especial my lord with due recommendation: your letter has been presented to me by Gentilino da Gradara and with it the bay pony (ronzino baiectino) the which you have sent me, and which appears in my eyes a fine caparison'd charger, upon which I intend to learn all there is to know about riding, in consideration of yr. paternal affection for which I thank your excellency thus briefly and pray you continue to hold me in this esteem ... (9/39)

In English the endless "the which," "upon which," and "for which" clauses, the consistent circumlocution, and the involuted address sound wholly absurd, especially since the subject of the letter is no more than the gift of a bay pony. Translated thus literally, the letter has neither the status of fifteenth-century document nor twentieth-century adaptation; it remains a curiosity, removed from a specific time-space context. The introduction of the Italian phrase "ronzino baiectino" is particularly skillful: "ronzino baiectino" does mean "bay pony," but in the context it sounds more like a zoological specimen or a rare disease.

The Malatesta Cantos "cut" back and forth between such literal translation on the one hand and intentional mistranslation on the other. We have one example of the latter in the above passage. Pound translates "uno grosso et apreciato corsiero" as "a fine caparison'd charger." "Apreciato" means "worthy" or "admirable"; "caparison'd" is a pure invention, used to enhance the bombastic formality of the child's letter. Frequently in the Malatesta Cantos, the straightforward expository prose of the original gives way to business English ("This to advise," "the said load"), illiterate spelling ("I think it advisabl that I shud go to rome to talk to mister Albert so as I can no what he thinks about it rite"-9 / 38), abbreviations ("yr. Lordship," "The Illus Sgr. Mr. Fedricho d'Orbino," "Sidg"), modern slang ("that nicknosed s.o.b. Feddy," "And old Sforza bitched us at Pesaro," "worked the wangle," "And he found 'em, the anti-Aragons, / busted and weeping in their beards"), Southern dialect ("provided you don't get too ornry," "But dey got de mos' bloody rottenes' peace on us"), and comic name-calling "old Wattle-Wattle," "Siggy darlint," the transformation of Giorgio Ranbutino into "Giorgio Rambottom").

Closely related to such artful mistranslation is the purposely incorrect rendering of the Italian itself. In the letter to Giovanni di Medici which opens Canto 8, for example, Pound has Sigismundo say: "And tell the Maestro di pentore / That there can be no question of / His painting the 
walls for the moment, / As the mortar is not yet dry / And it wd. be merely work chucked away / (buttato via) ..." (8/28). In the original, ${ }^{57}$ the Italian phrase is gettata via, which means "thrown away." Pound substitutes the harsh "buttato via," partly to suit his own meaning-"chucked away"and partly, no doubt, for comic sound effect.

One of Pound's most effective ways of distorting perspective is to juxtapose a snatch of Italian with the "official" Latin document relating to the same thing, and then to tack on an English conclusion, thus incorporating linguistic conventions of various centuries. Canto 9 , for instance, begins on a note of quasi-Biblical repetition-"One year floods rose, / One year they fought in the snows, / One year hail fell"-then moves through a series of paratactic "And ..." clauses ("And the Emperor came down and knighted us, / And they had a wooden castle set up for fiesta"), gives way to the series of "real" letters discussed above, and then comes to the following cli$\max$ :

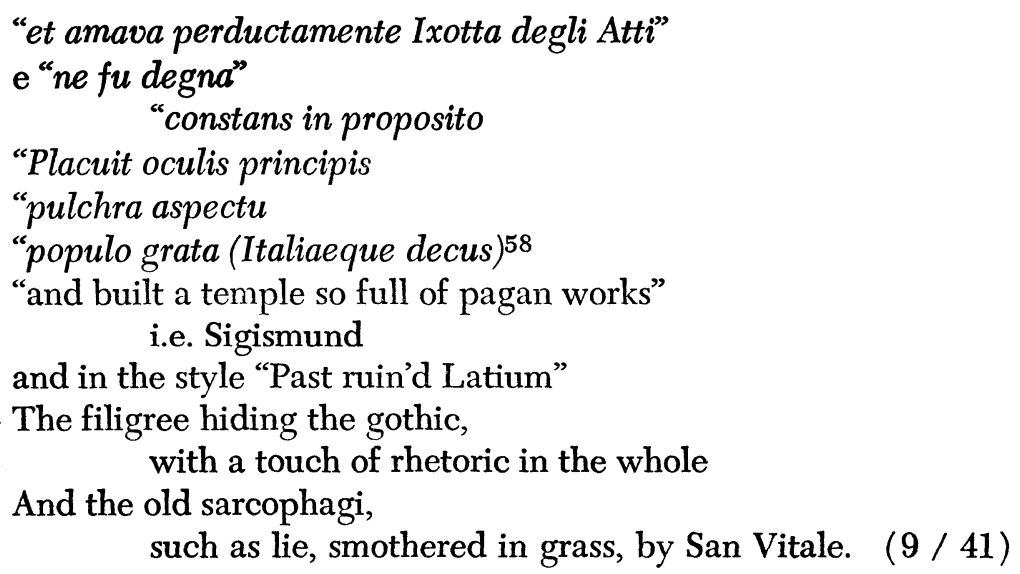

The Italian lines (1-2) were written by Pope Pius II. The four Latin lines that follow come from a fifteenth-century chronicle attributed to Alessandro da Rimini, although Pound condenses and rephrases the original. The conjunction of the Italian and Latin encomiums emphasizes Isotta's special charms and justifies Sigismundo's boundless passion for her. But now both are further set off by the English conclusion, which begins with a translation from the Latin chronicle ("and built a temple so full of pagan works"), modulates into American shorthand ("i.e. Sigismund"), and then provides a variation of Walter Savage Landor's Victorian poem, "Past ruined Ilion Helen lived." The love affair of Sigismundo and Isotta degli Atti is thus viewed from the perspective of three centuries as well as three languages. In the final lines of the Canto, Pound reverses the movement, and 
we come back to the old sarcophagi, "such as lie, smothered in grass, by San Vitale"-that is, to the early Christian world. We also come back to the poet who contemplates all these things, whose vision of the sarcophagi at San Vitale has prompted his meditation on Malatesta in the first place.

The Malatesta Cantos do not, then, recreate history; they decompose and fragment historical time so as to create a new landscape without depth, what Jean-Pierre Richard calls, with reference to Rimbaud, an "anti-paysage." 59 Here a comparison of Pound to Yeats is instructive. A Symbolist poet like Yeats compares and contrasts historic cultures: Byzantium is, in some respects, comparable to fifth-century Athens; it stands in contrast to the pulsating, sensual country of the young-Ireland. But Pound makes no such comparisons. Instead of contrasting culture A to culture B, he adopts a relativist stance to the culture in question. Thus the lengthy Latin statement describing the auto-da-fé of Sigismundo, complete with bibliographical references to its sources $(10 / 43-44)$, is exploded by the slangy passage that follows it:

So that in the end that pot-scraping little runt Andreas

Benzi, da Siena

Got up to spout out the bunkum

That that monstrous swollen, swelling s.o.b.

Papa Pio Secundo

Aeneas Silvius Piccolomini

da Siena

Had told him to spout, in their best bear's-greased latinity ...

And this narrative, rendered in Pound's best Western twang, is again displaced by a Latin passage, listing the sins for which Sigismundo was excommunicated: "Stupro, caede, adulter, / homicida, parricida ac periurus," and so on.

The mode of the Malatesta Cantos is thus quite unlike that of Mauberley with its symbolic allusions to the "mousseline of Cos" and "Pierian roses." Pound is moving from a poetry of product to one of process, from an aesthetic of contemplation to one of participation. One could, for instance, study the shifting pronouns in these Cantos as one form of radical disjunction. Thus in Canto 9, Pound begins as chronicler ("One year floods rose ...") but suddenly switches in line 28 to the first-person plural-"And old Sforza bitched us at Pesaro"-adopting for the moment Sigismundo's own point of view. The same thing happens in the letters interspersed through Cantos 10 and 11, where we get sudden shifts such as "And we sit here. I have sat here / For forty four thousand years" (11 / 50).

The perspective is thus constantly shifting as in a cubist painting. One 
can see events, people, and things from many sides, simultaneously. Pound's definition of a VORTEX as "a radiant node or cluster . . . from which, and through which, and into which, ideas are constantly rushing" (GB, 92) is entirely applicable to the technique of the Malatesta Cantos. The poet is everywhere present, placing and displacing his figures upon a shallow screen; the reader enters that screen, constantly brought up short by shifts in language, levels of style, linguistic deformation, and so on. Pound discards tropes of similarity like metaphor and symbol for those of contiguity -individual images are related metonymically as parts of a mosaic that must be reassembled with the reader's help.

Pound's later Cantos do not consistently follow the pattern I have been describing with respect to the Malatesta sequence. Indeed, no poem the size of the Cantos can be entirely consistent. Interestingly, those Cantos that do revert to the more representational, Symbolist mode of the earliest Cantos are generally the famous anthology pieces-such showpieces as Canto 13 ("Kung walked / by the dynastic temple"), 30 ("Compleint, compleynt I hearde upon a day"), 45 (the Usura Canto), 49 (the "Seven Lakes" Canto), or the second half of 81 , which culminates in the celebrated "Pull down thy vanity!" passage. But although space forbids an investigation of the later Cantos here, I would like to suggest that the Pisan sequence (7284 ), generally held to contain some of Pound's finest poetry, carries on the mode of the Malatesta Cantos and, indeed, brings that mode to its logical conclusion. Sharply-etched literal images composing flat surfaces, multilinguistic perspective, syntactic and verbal dislocation-all these features recur in the Pisan Cantos, but now the fragmentation described earlier becomes more and more extreme; the basic unit is no longer the verse paragraph or group of lines as in Canto 9, but often the individual line, word group, or even the single ideogram.

I would not want to press the similarity between the Cantos and the poetry of Rimbaud. The differences between the two are all too obvious. Where Rimbaud is dreamlike, hallucinatory, incantatory, visionary, Pound is matter-of-fact, literal, documentary, down-to-earth. Nevertheless, I would argue that the Cantos are much closer to Rimbaud's poetry (especially to the Saison and the Illuminations which Pound pretended to ignore) than they are to, say, the Odyssey or the Divina Commedia. I realize that what I am saying is tantamount to heresy, that Pound's debt to Homer and Dante is accepted as a historical fact. But however much Pound may have thought he was influenced by Homer and Dante, his structures of decomposition and fragmentation have, formally speaking, almost nothing to do with the architectural design of the Odyssey or the "Aquinas-map" of the Commedia. Structurally, the Malatesta or Pisan Cantos may be said to fulfill Pound's aim: to forge a conscious aesthetic out of Rimbaud's random intuitions. 
For Rimbaud was, as Richard says, "le premier poète moderne" (p. 249 ), the poet for whom the world ceased to be an open dictionary, a body of significations to be deciphered, and whose landscapes have, accordingly, nothing behind them. In Rimbaud's world, the poet is no longer a perceiving self, imposing unity on what he observes. He does not contemplate the objects before him or comment on their value. Rather, he projects himself into these objects, which thus take on a life of their own. For the first time things present themselves to us with no overt mediation on the poet's part; they become "des pièces de conviction," endowed with their own radiance. And so "la poésie objective" is born. ${ }^{60}$

The Malatesta Cantos, written in 1923 when Pound's interest in Rimbaud was coming to its height, represent Pound's first experiment with such "poésie objective." The uncomfortable symbolism of Mauberley, with its panoply of stuffed-satin drawing rooms and topaz eyes, gives way to passages like the following from Canto 80 in the Pisan sequence:

Judith's junk shop

with Theophile's arm chair

one cd/ live in such an apartment

seeing the roofs of Paris

The old trees near the Rue Jacob

Ça s'appelle une mansarde

were propped up to keep them from falling . . .

$(80 / 504-505)$

Here the little junk shop of Judith Gautier, displaying the armchair of her poet-father, the French explanation to the innocent foreign tourist ("Ça s'appelle ..."), the crumbling mansard roofs of nineteenth-century Paris, and the old trees near the Rue Jacob that seem to prop them up-all these images retain a life of their own, a literalness that defies our efforts to delve beneath the surface, to search for a second level of meaning. The poet of "Au Cabaret-Vert" and "Les Assis" would have approved.

\section{NOTES}

1 "Excerpts from a Critical Sketch," Selected Essays (New York: Random House, 1954), p. 107.

2 The Selected Letters of Ezra Pound, ed. D. D. Paige (New York: New Directions, 1971), p. 323. Subsequently noted as SL.

Comparisons of the Cantos to the Odyssey and to the Divina Commedia are legion. Recent commentators have looked for other unifying principles. Walter Baumann, in The Rose in the Steel Dust: An Examination of the Cantos of Ezra Pound (Bern: Francke Verlag, 1967), argues that the central structural principle 
is Pound's search for the ideal Neoplatonic city of spiritual love. Daniel D. Pearlman, in The Barb of Time: On the Unity of Ezra Pound's Cantos (New York: Oxford, 1969), finds the "major form" of the Cantos to emerge from the tension between linear time and cyclical time. But Eva Hesse, in her "Introduction" to New Approaches to Ezra Pound (Berkeley and Los Angeles: Univ. of California Press, 1969), pp. 13-54, argues convincingly that a poem like the Cantos is intentionally open-ended, that it cannot be expected to display Aristotelian unity.

3 "Rimbaud in Our Time" (1939) in Selected Essays (Chicago: Univ. of Chicago Press, 1970), p. 57.

${ }^{4}$ Rimbaud (Milan: All Insegna del Pesce d'Oro, 1957). Pound's translations of these five poems are reprinted in Ezra Pound, Translations (New York: New Directions, 1963), pp. 434-438. Note that Pound translates only the octave of the sonnet "Venus Anadyomène," and that the poem he calls, following earlier texts, "Comedie en trois baisers" is known, in all editions of Rimbaud's poetry subsequent to 1934, as "Première Soirée." See Rimbaud, Oeuvres, ed. Suzanne Bernard (Paris: Garnier, 1960), p. 374.

5 A Study in French Poets, The Little Review, 4, no. 10 (Feb., 1918), 3-61. Rpt. with minor changes in Instigations (New York: Boni and Liveright, 1920), pp. 3-105.

6 For the publishing history of these Cantos, see Myles Slatin, "A History of Pound's Cantos I-XVI, 1915-1925," American Literature, 35 (May, 1963), 183195.

7 For a thorough treatment of the Gautier influence on Mauberley, see John J. Espey, Ezra Pound's Mauberley: A Study in Composition (London: Faber and Faber, 1955), pp. 25-48.

8 The phrase is Pound's. See Poem II of Part I of Hugh Selwyn Mauberley in Personae: The Collected Poems of Ezra Pound (New York: New Directions, $1926)$, p. 188. Subsequently noted as Personae.

9 See esp. Hugh Kenner, The Pound Era (Berkeley and Los Angeles: Univ. of California Press, 1971), pp. 128-144, 173-191; Donald Davie, Ezra Pound: Poet as Sculptor (1964; rpt. New York: Galaxy Books, 1968), Chapter III passim, and pp. 228-229.

10 Ezra Pound: The Image and the Real (Baton Rouge: Louisiana State Univ. Press, 1969), Chapters 1 and 2 passim, esp. pp. 16-25, 29, 56-57, 62-63. Schneidau's is the best general treatment of Pound's poetics. An indispensable book.

In Romantic Image (1957; rpt. New York: Vintage, 1964), Frank Kermode argues that "the Hulmian Image-precise, orderly, anti-discursive, the product of intuition-is the Symbol of the French poets given a new philosophical suit" (p. 130). Or again, "The Cantos ... are the only kind of long poem the Symbolist aesthetic will admit" (p. 136). Schneidau refutes this claim on pp. 38-39.

11 "Status Rerum," Poetry, I (1913), 125. See also Schneidau, pp. 15-17.

12 "The Approach to Paris, V," The New Age, 2 Oct., 1913; rpt. in Ezra Pound, Selected Prose 1909-1965, ed. William Cookson (London: Faber and Faber, $1973)$, p. 343. 
13 Gaudier-Brzeska (New York: New Directions, 1970), p. 84. Subsequently noted as GB.

14 See Hugo Friedrich, The Structure of Modern Poetry (1956), trans. Joachim Neugroschel (Evanston, Illinois: Northwestern Univ. Press, 1974), p. 57.

15 Pound adds the Note: "Jewel stairs, therefore a palace. Grievance, therefore there is something to complain of. Gauze stockings, therefore a court lady, not a servant who complains. Clear autumn, therefore he has no excuse on account of weather. Also she has come early for the dew has not merely whitened the stairs, but has soaked her stockings. The poem is especially prized because she utters no direct reproach" (p. 132).

16 A somewhat similar case is made by Wai-lim Yip in Ezra Pound's "Cathay" (Princeton: Princeton Univ. Press, 1969), pp. 67-68.

17 The phrase is Hugh Kenner's; see The Pound Era, p. 360. The three Cantos were published in the June, July, and August, 1917, issues of Poetry, X, pp. 113$121,180-188,248-253$.

18 Poetry, X (June, 1917), p. 117.

19 This explanation of the "sardine catch" is found in Kenner, The Pound Era, p. 357.

20 See Mallarmé, Hérodiade, Part I, lines 38-50.

21 See Myles Slatin, “A History of Pound's Cantos I-XVI,” 192.

22 Little Review, 4.

${ }^{23}$ In Rimbaud, Complete Works, Selected Letters, trans. and ed. Wallace Fowlie (1966; rpt. Phoenix Books, 1967), these five lines are translated as follows:

They have grafted in epileptic loves

Their ludicrous bone structure to the large black skeletons

Of their chairs; their feet on the rickety rails

Are entwined mornings and evenings!

These old men have always made one tress with their seats . .

24 In The Pound Era (pp. 207-216), Kenner shows that Pound took four connected poems from the Fenollosa Ms. to make his synthesis.

25 L'Influence du Symbolisme Français sur la Poésie Americaine (1910-1920) (Paris: Librairie Honoré Champion, 1929), p. 151.

26 "How to Read," Literary Essays of Ezra Pound, ed. T. S. Eliot (London: Faber and Faber, 1954), pp. 25, 27, 33. Subsequently noted as LE.

27 Eliot, "Introduction to Ezra Pound: Selected Poems, 1928," rpt. in Ezra Pound: A Critical Anthology, ed. J. P. Sullivan (Baltimore: Penguin Books, 1970), pp. 108-109.

28 New Bearings in English Poetry (London: Chatto and Windus, 1954), p. 235.

29 "Ezra Pound," Poetry, 68 (Sept., 1946); rpt. in Ezra Pound: A Collection of Critical Essays, ed. Walter Sutton, Twentieth-Century Views (Englewood Cliffs, N.J.: Prentice-Hall, 1963), p. 23. 
30 "XXX Cantos of Ezra Pound: An Incursion into Poetics," Scrutiny, 2 (1933); rpt. in Ezra Pound: A Critical Anthology, ed. Sullivan, p. 139.

31 The Poetry of Ezra Pound: Forms of Renewal, 1908-1920 (Berkeley and Los Angeles: Univ. of California Press, 1969), p. 163. John Espey similarly calls Mauberley "a thumbnail outline of many themes in the Cantos" (Ezra Pound's Mauberley, p. 106); Sr. Bernetta Quinn in Ezra Pound: An Introduction to the Poetry (New York: Columbia Univ. Press, 1972) calls it "a rehearsal for his masterpiece" (p. 74).

32 See K. K. Ruthven, A Guide to Ezra Pound's Personae (1926) (Berkeley and Los Angeles: Univ. of California Press, 1969), p. 106.

${ }^{33}$ See Gaudier-Brzeska, pp. 89, 92.

${ }^{34}$ See Ruthven, p. 140. The allusion is to Sappho, LXXI: "for you have no part in the roses that come from Pieria."

35 Witemeyer reads this passage differently. He argues that "Mauberley has succeeded in transforming the lady's eyes into beautiful gems despite the inadequate artistic forces at his command. In celebrating 'topaz' eyes he is carrying on the work of his ancestors who celebrated 'yeux glauques'" (p. 186). But the context in which "Circe's hair" is reduced to a "basket-work of braids" suggests the opposite reading. In either case, one should note, "topaz" eyes function symbolically.

${ }^{36}$ Criterion, July, 1932, cited by Espey, p. 25.

37 The Cantos of Ezra Pound (New York: New Directions, 1971). All subsequent references are to this edition of the Cantos. The designation $4 / 13$ means that the reference is to Canto 4, page 13.

38 John H. Edwards and William W. Vasse, Annotated Index to the Cantos of Ezra Pound: Cantos I-LXXXIV (Berkeley and Los Angeles: Univ. of California Press, 1971), p. 260. Subsequently noted as Edwards and Vasse. I am indebted to the Index throughout the discussion of the Cantos that follows.

39 Early commentators tended to take the reference seriously; see, for example, R. P. Blackmur, "Masks of Ezra Pound," Hound and Horn, 7 (1934); rpt. in Ezra Pound: A Critical Anthology, ed. Sullivan, p. 165. Espey notes, on the other hand, that in The Egoist of March-April, 1919, Pound said, "Pindar is a pompier and his 'Anaxiforminges hymnoi' etc. ought to be sent to the dust bin ..." (my transliteration of the Greek). See Espey, pp. 86-88.

40 The Poetry of Ezra Pound (Norfolk, Conn.: New Directions, 1951), p. 316.

41 Baumann, The Rose in the Steel Dust, pp. 24-25, 36-40.

42 Baumann, pp. 19-20.

43 In its final version, this line was followed by the lines "And we sit here $\ldots$ / there in the arena ..." See $4 / 16$.

44 See Baumann, pp. 40-42; Edwards and Vasse, p. 211.

45 See Slatin, 188-189. The original Canto 6, for example, was twenty-four lines shorter, ending with the line, "who sheds such light in the air." See 6 / 22. 46 Criterion, I, no. 4 (July, 1923), 363-384. In revising Canto 9-the future Canto 8-Pound added four lines to the beginning: "These fragments you have shelved (shored)," and so on. See $8 / 28$. In the original version of this Canto, 
the word "and" that ends the poem was set off in a separate line. Such minor changes in lineation are typical of Pound's revision of the Malatesta Cantos.

${ }^{47}$ See esp. Forrest Read, "Pound, Joyce, and Flaubert: The Odysseans," in New Approaches to Ezra Pound, ed. Eva Hesse, pp. 125-44. Read argues that Pound and Joyce make similar use of the Ulysses motif (the voyage structure, the concept of the all-round man, of "outis," of levels of history, and so on). This is undoubtedly true, but the end-products are entirely different.

48 Criterion, 1 (January, 1923), 143-156.

49 “The Approach to Paris, II" The New Age (11 Sept., 1913), 577-579; rpt. in Cyrena Pondrom, The Road from Paris: French Influence on English Poetry, 1900-1920 (Cambridge, England: Cambridge Univ. Press, 1974), p. 175.

50 See, for example, Sr. Bernetta Quinn, Ezra Pound: An Introduction, pp. 105-106; Donald Davie, Ezra Pound: Poet as Sculptor, pp. 129-131.

51 "The Adventures of Messire Wrong-Head," ELH, 32 (June, 1965), 242.

52 Davie, p. 126.

53 Criterion (July, 1923), 364; Cantos 8 / 28. From now on, references are to the Cantos rather than to the Criterion version, since the two are almost identical.

54 " 'The Music of a Lost Dynasty': Pound in the Classroom," Boston University Journal, 21 (Winter, 1973), 38. Carne-Ross' discussion of the problems inherent in "interpreting" the Cantos, specifically Canto 81 , is one of the best I have seen, and I owe a great deal to it in this essay. Carne-Ross insists: "Pound is not polysemous; his first level doesn't point beyond itself. . . . The green tip that pushes through the earth in spring does not stand for or symbolize man's power of spiritual renewal. . . That green thrust is itself the divine event" (38).

55 Pound's main source is Charles Yriarte, Un Condottière au XVe Siècle (Paris, 1882), especially the appendix, "Notes-Documents-Commentaires." This particular letter is cited in full on p. 381.

56 See Yriarte, p. 445.

57 Yriarte, p. 381.

58 Edwards and Vasse in the Index translate the passage as follows: "and he loved Isotta degli Atti to distraction / and 'she was worthy of him' / 'constant in purpose' / 'she was pleasing to the eyes of the prince' / 'beautiful to look at' / 'she was liked by the people (and the honor of Italy)." See also Yriarte, p. 155.

59 Poésie et Profondeur (Paris: Editions du Seuil, 1955), p. 240.

60 Richard, pp. 240-241. 